\title{
A new Styloptocuma species (Crustacea, Cumacea) from hydrothermal vent fields of the Lau and North Fiji basins (West Pacific)
}

\author{
Jordi CORBERA \\ Carrer Gran 90, E-08310 Argentona, Catalonia (Spain) \\ corbera@sct.ictnet.es
}

Michel SEGONZAC

Muséum national d'Histoire naturelle, Département Milieux et Peuplements aquatiques, case postale 53, 57 rue Cuvier, F-75231 Paris cedex 05 (France)

segonzac@mnhn.fr

KEY WORDS

Crustacea,

Cumacea,

Nannastacidae,

Styloptocuma,

deep-sea,

hydrothermal vents,

back-arc basins,

southwestern Pacific, new species.
Corbera J. \& Segonzac M. 2010. - A new Styloptocuma species (Crustacea, Cumacea) from hydrothermal vent fields of the Lau and North Fiji basins (West Pacific). Zoosystema 32 (3) : 439-447.

\section{ABSTRACT}

A new species of Nannastacidae, Styloptocuma darwini n. sp., is described from three hydrothermal sites in the back-arc basins of the southwestern Pacific: White Lady (North Fiji Basin), Hine Hina and Tu’i Malila (Lau Basin). Styloptocuma darwini n. sp. resembles S. pleonserratum Mühlenhardt-Siegel, 2005, from the Angola Basin and S. spinosum Petrescu, 2006, from the southeastern Australian slope, but differs from both by having a serrate antennal notch margin and transverse rows of spines on pereonites. The new species is associated with hydrothermal vent assemblages known from the southwestern Pacific back-arc basins. Affiliation to known families tends to indicate that the modern vent cumacean fauna may have originated from the surrounding deep-sea environment but also from the shallow-water vents or cold seeps, which acted as refugia during past global anoxic events in the deep sea. 
MOTS CLÉS

Crustacea,

Cumacea,

Nannastacidae,

Styloptocuma,

mer profonde,

sources hydrothermales,

bassins arrière-arcs,

sud-ouest Pacifique, espèce nouvelle.

\section{RÉSUMÉ}

Une nouvelle espèce de Styloptocuma (Crustacea, Cumacea) de sites hydrothermaux des bassins de Lau et nord-fidjien (Pacifique occidental).

Une nouvelle espèce de crustacé cumacé Nannastacidae, Styloptocuma darwini n. sp., est décrite de trois sites hydrothermaux des bassins arrière-arcs du sudouest Pacifique: White Lady (bassin nord-fidjien), Hine Hina et Tu’i Malila (bassin de Lau). Styloptocuma darwini n. sp. ressemble à $S$. pleonserratum Mühlenhardt-Siegel, 2005, du bassin de l'Angola, et à S. spinosum Petrescu, 2006, de la pente du sud-est australien, mais diffère de ces deux espèces par la présence d'un bord d'encoche antennaire dentelé et de rangées d'épines transversales sur les péréionites. La nouvelle espèce est associée aux communautés hydrothermales connues des bassins arrière-arcs du sud-ouest Pacifique. La parenté avec des familles connues indique que la faune moderne des cumacés hydrothermaux a pu provenir de l'environnement abyssal, mais également des milieux hydrothermaux peu profonds ou de suintements froids, avant d'avoir trouvé refuge pendant les événements anoxiques globaux passés dans le milieu abyssal.

\section{INTRODUCTION}

Although cumaceans are quite common and diverse in deep waters (see among others Jones \& Sanders 1972), little is known about the cumacean fauna living in hydrothermal vent environments. The first report of such cumaceans was published in the second edition of the Handbook of Deep-Sea Hydrothermal Vent Fauna (Desbruyères et al. 2006) by Corbera (2006) who reported two species, Atlantocuma bidentatum Ledoyer, 1988 and Bathycuma brevirostre (Norman, 1879), from the Parigo (East Pacific Rise) and Lucky Strike (Mid-Atlantic Ridge) hydrothermal vent fields, respectively. Later on, Corbera et al. (2008) described a new genus and species of Nannastacidae Bate, 1866, Thalycrocuma sarradini Corbera, Segonzac \& Cunha, 2008, from the Lucky Strike hydrothermal vent field and also recorded the presence of Procampylaspis sp. and Makrokylindrus sp. in the same area. This scarce representation of cumaceans in the fauna of such chemosynthetic-based marine ecosystems may be due to the preference of these crustaceans for soft bottoms but also to the lack of adequate sampling.
The genus Styloptocuma was erected by Băcescu $\&$ Muradian (1974) in order to accommodate a group of species, all living in deep waters, previously included in the genus Cumella Sars, 1865 but having a narrow and elongate eyelobe without visual elements and elongate appendages. Jones (1984) considered it a synonym of Cumella. Later, Watling (1991), in his revision of the family Nannastacidae, considered Styloptocuma as a subgenus of Cumella. However, Petrescu (2000) argued again for the generic level of Styloptocuma and pointed out that it exhibits a mixture of characters found in Cumella and Nannastacus Bate, 1865.

The first known species of Styloptocuma were restricted to the deep Atlantic Ocean but recently new species have been described or recorded from Australian and Antarctic waters (Petrescu 2006; Corbera et al. 2009) showing the wide distribution of this genus in deep waters.

The study of the material collected during the American cruise TUIM06MV provided three specimens of an unknown species of Styloptocuma. The present article describes them as a new species. 


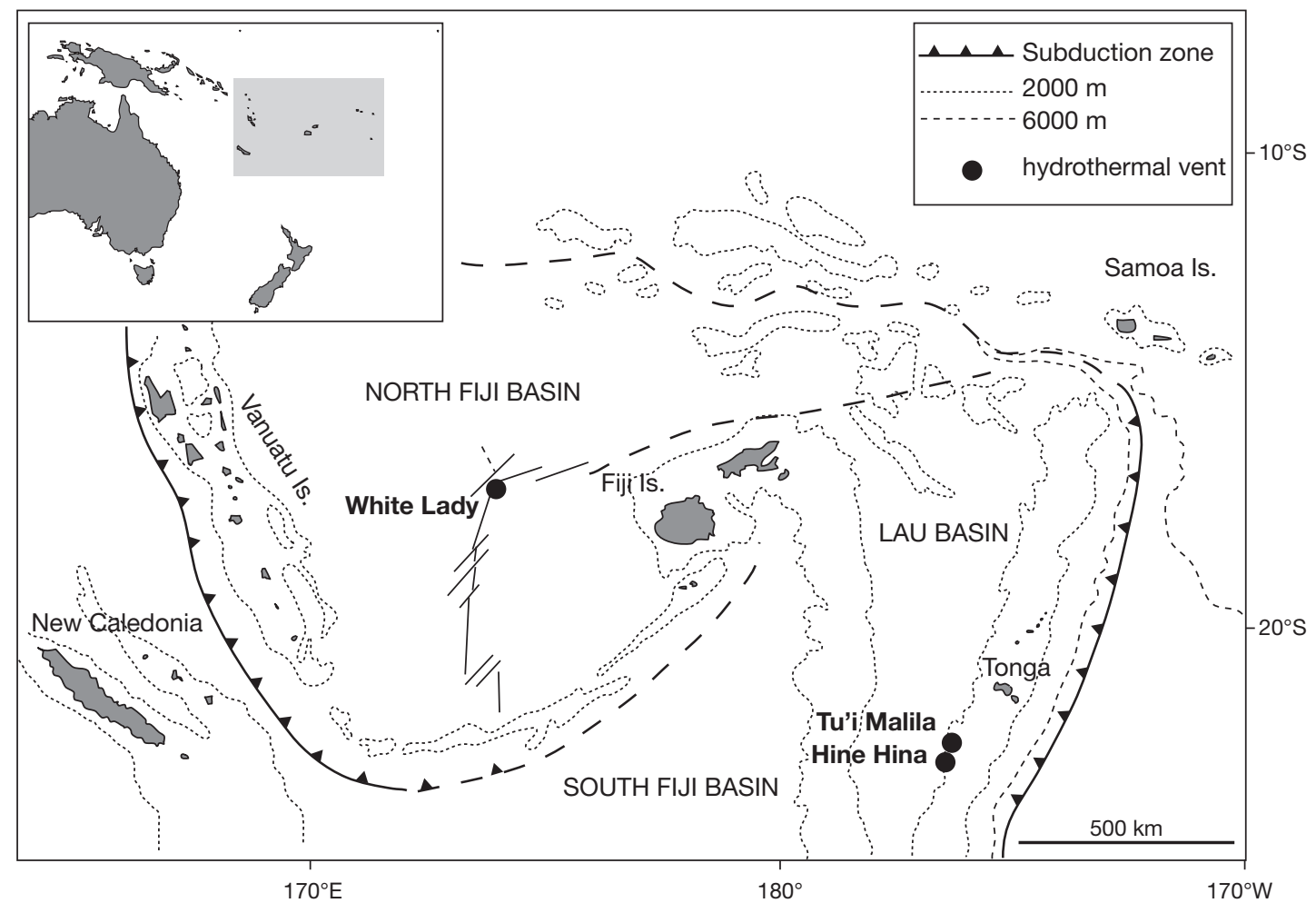

FIG. 1. - Localization of the three hydrothermal vent fields in the West Pacific back-arc basins where Styloptocuma darwini n. sp. was collected.

\section{MATERIAL AND METHODS}

The specimens studied here were collected during the TUIM06MV Cruise on the Lau and North Fiji basins (southwest Pacific) in May 2005. They were collected with a suction sampler during three dives (at depths between 1845 and 1990 m; Fig. 1) mounted on the ROV Jason II submersible supported by the RV Melville. For the morphological observations, a specimen was decalcified and dissected in lactic acid and stained with chlorazol black. It was then mounted in Fauré medium and sealed with nail varnish. This procedure seems to remove some external structures such as the rows of spines. Drawings were prepared using a camera lucida on an Olympus microscope. The terminology follows Băcescu \& Petrescu (1999). The specimens are deposited at the Muséum national d'Histoire naturelle, Paris (MNHN).

\section{SYSTEMATICS}

Order CUMACEA Kröyer, 1846 Family NANNASTACIDAE Bate, 1866 Genus Styloptocuma Băcescu \& Muradian, 1974

Styloptocuma darwini $\mathrm{n}$. sp.

(Figs 2-4)

Type Material. - SW Pacific, near Fiji Islands, RV Melville, ROV Jason II, TUIM06MV cruise, R. C. Vrijenhoek (USA) coll., dive 144 (slurp 1), 21.V.2005, Lau Basin, Tu’i Malila vent site, 21 $59.34^{\prime} \mathrm{S}, 176^{\circ} 39.09^{\prime} \mathrm{W}$, $1891 \mathrm{~m}, 1$ ㅇ holotype (MNHN-Cu1136). - Dive 146 (box 5), 23.V.2005, Lau Basin, Hine Hina vent site, $22^{\circ} 32.33^{\prime} \mathrm{S}, 176^{\circ} 43.07^{\prime} \mathrm{W}, 1845 \mathrm{~m}, 1$ \% paratype dissected in two slides (MNHN-Cu1137). - Dive 152, slurp gun 1, 31.V.2005, North Fiji Basin, White Lady vent site, $16^{\circ} 59.44^{\prime} \mathrm{S}, 173^{\circ} 54.90^{\prime} \mathrm{E}, 1990 \mathrm{~m}, 1$ ㅇ paratype (MNHN-Cu1138). 


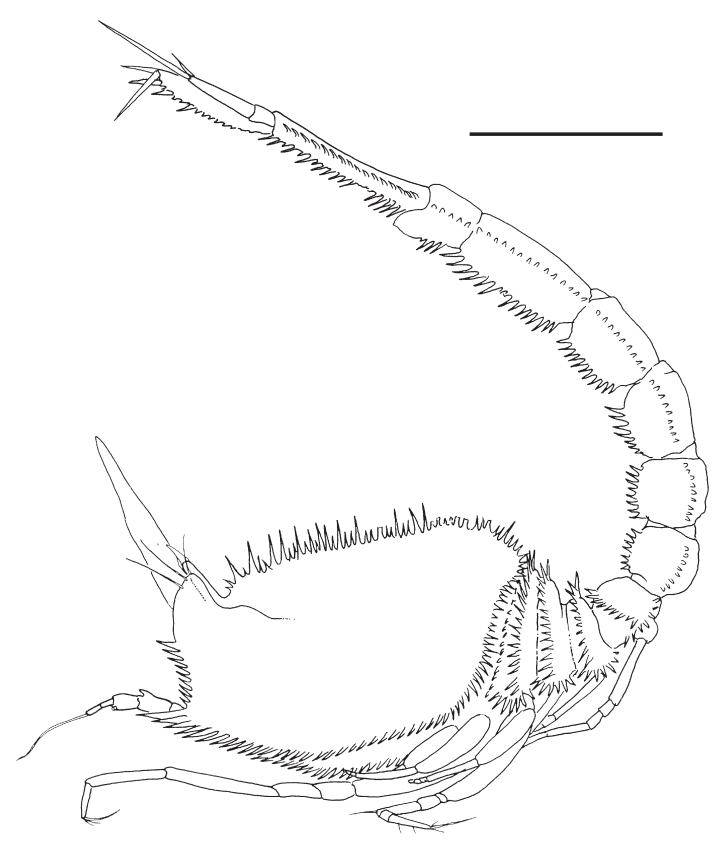

FIG. 2. - Styloptocuma darwini n. sp., immature $q$ holotype (MNHN Cu1136), whole animal in lateral view. Scale bar: $0.5 \mathrm{~mm}$.

ETYMOLOGY. - The new species is respectfully named in honour of Charles Darwin commemorating the second centenary of his birth and the 150th anniversary of the publication of On the Origin of Species..., a book that changed our conception of the living world and its history on Earth.

DiAgnOSIS. - Pseudorostrum upturned at an angle of more than $45^{\circ}$, eyelobe exceeding the length of pseudorostral lobes with a distal spine, antennal notch serrate, pereonites with a transverse row of spines, pleonites with a middorsal and a lateral row of spines.

\section{DESCRIPTION}

Preadult female $2.5 \mathrm{~mm}$ total length. Carapace (Fig. 2) about $1 / 3$ of total length with a middorsal and a lateral row of spines; eyelobe narrow and elongate reaching beyond the tip of pseudorostrum, without optical lenses and with a terminal spine; pseudorostrum upturned at an angle of more than $45^{\circ}$; antennal notch wide with the margin serrate; anterolateral angle acute, lower margin serrate. Pereonites with a transverse row of spines. Pleonites with middorsal and lateral rows of spines.
Antennula (Fig. 4A), peduncle 3-articulate; article 1 longer than articles 2 and 3 combined lengths; article 2 slightly longer than article 3 , with a tubercle; main flagellum lost; accessory flagellum 2-articulate. Left mandible (Fig. 3B) with three teeth on the pars incisiva, six setae between pars incisiva and truncated pars molaris (seven setae on right mandible; Fig. 3A). Maxillula (Fig. 3C) palp with a single filament, inner endite with four setae, two simple, one trifid and one serrulate. Maxilla (Fig. 3D) with transverse row of setules on the protopod; endites exceeding the protopod, with simple and serrulate setae.

Maxilliped 1 (Fig. 3E) basis with four pappose setae on inner margin, distally produced reaching carpus; carpus with six flattened hand-like-side setae on the inner margin, and a long pappose setae on distal outer corner; propodus with three setae on distal inner corner, the longest pappose and exceeding the tip of dactylus. Maxilliped 2 (Fig. 3F) basis shorter than rest of appendage, with a plumose seta on distal inner corner; merus with two long plumose setae on inner margin; carpus longer than merus with two pappose and two simple setae on inner margin; propodus shorter than carpus, with three pappose and one simple setae on inner margin and a plumose seta on distal outer corner. Maxilliped 3 (Fig. 4B) with well-developed exopod, basis as long as rest of appendage, not expanded distally, wider than ischium, with three long plumose and a simple seta on the broad part of distal margin and two pappose setae on inner margin; merus with a plumose and a simple seta on inner margin and a long plumose seta on distal outer corner; carpus longer than merus, with a plumose seta on inner margin and a long plumose seta on distal outer corner; propodus longer than carpus with simple seta on inner margin and a simple one on outer distal corner; dactylus half length of propodus.

Pereopod 1 (Fig. 4C) with well-developed exopod, basis slightly longer than the following three articles combined lengths, with two simple and one plumose setae distally; merus longer than ischium; carpus twice as long as merus with simple setae on both margins; propodus slightly shorter than carpus and more than twice as long as dac- 


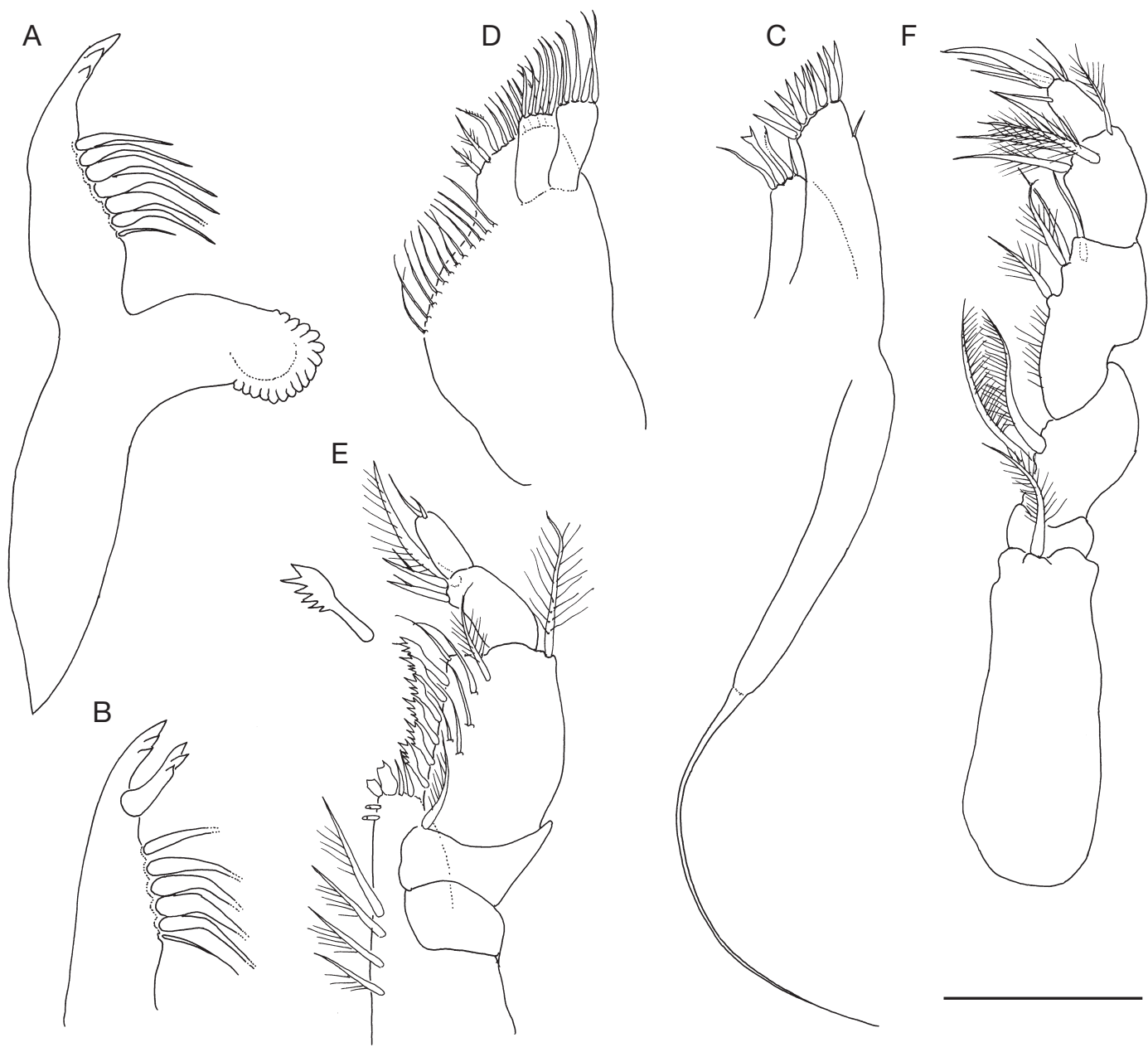

FIG. 3. - Styloptocuma darwini n. sp., immature $९$ paratype (MNHN Cu1137): A, right mandible; B, left mandible; C, maxillule; D, maxilla; E, maxilliped 1; F, maxilliped 2. Scale bar: $0.1 \mathrm{~mm}$.

tylus. Pereopod 2 (Fig. 4D) with well-developed exopod, basis shorter than rest of appendage, with small simple setae on both margins; ischium very short; merus shorter than carpus; carpus with a simple seta on margins and on distal lower corner; propodus half length of carpus; dactylus more than twice as long as propodus, with two simple setae on lower margin, one on upper margin and three terminally (the longest serrulate and longer than article). Pereopod 3 (Fig. 4E) basis longer than rest of appendage, with simple setae on anterior margin; ischium with two simple setae on distal corner; merus with two simple setae on the margin; carpus twice as long as merus; propodus longer than half length of carpus. Pereopod 4 (Fig. 4F) basis shorter than rest of appendage; merus with a simple seta on distal corner; carpus twice as long as merus; propodus longer than half length of carpus, with a small simple seta on distal corner. Pereopod 5 (Fig. 4G), basis shorter than rest of appendage; carpus three times as long as merus; propodus longer than merus.

Uropod peduncle (Fig. 4H) longer than pleonite 5 and 1.5 times as long as endopod, with a row of 
B
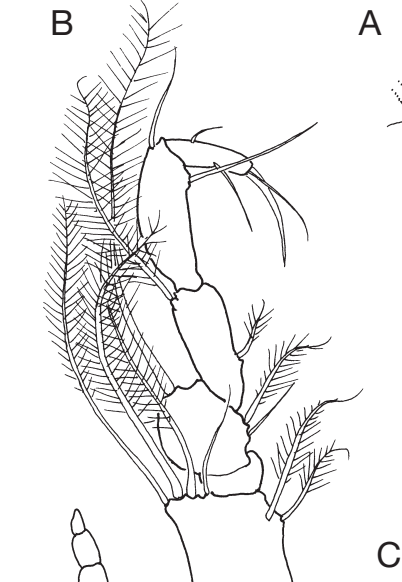

C

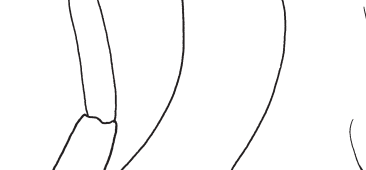

(1)
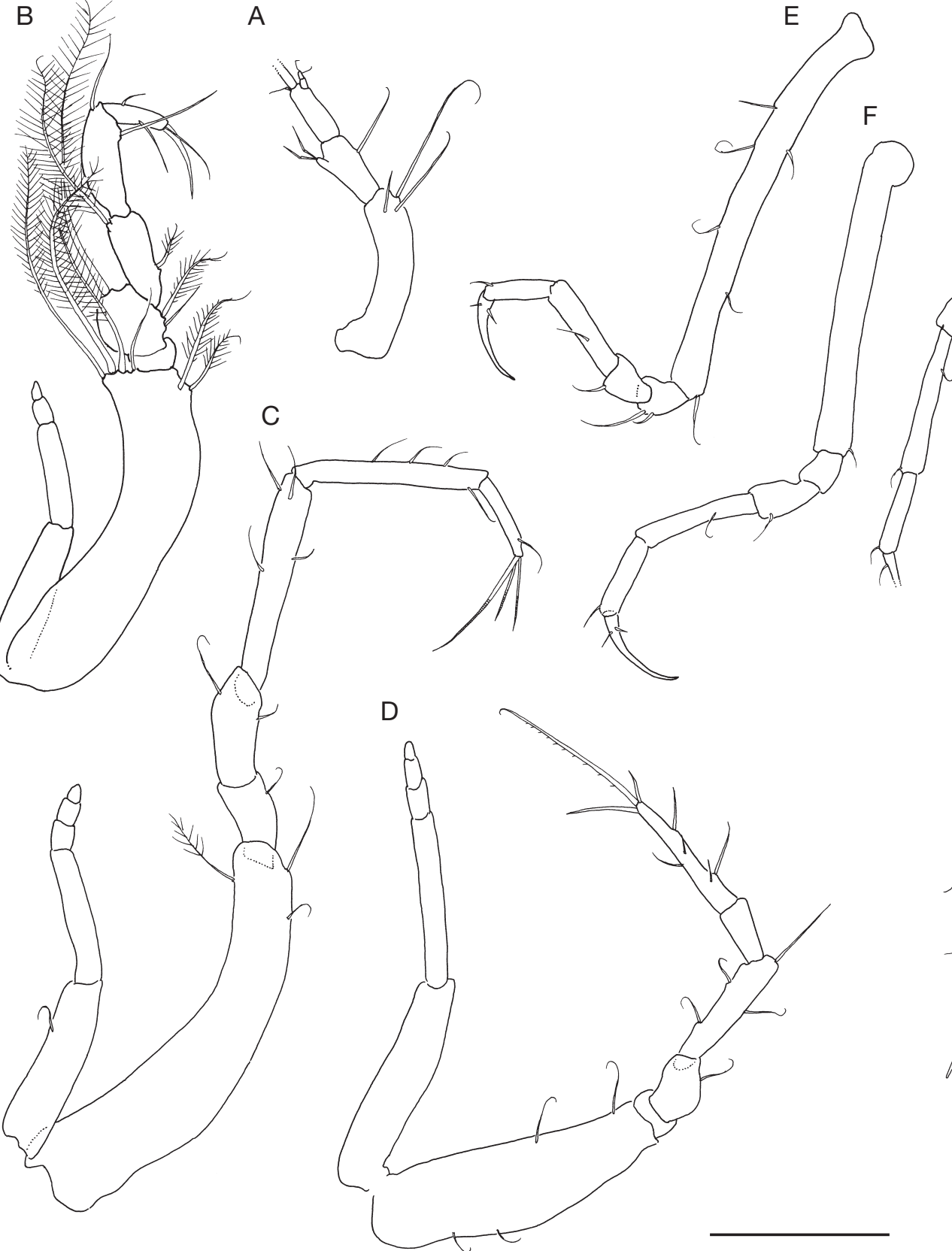

$\mathrm{E}$
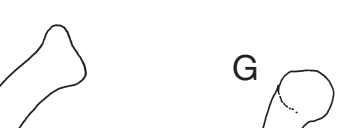

$\mathrm{F}$
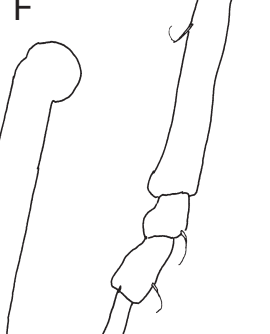

$\mathrm{H}$

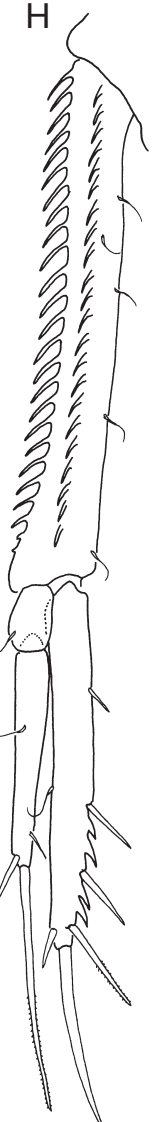

FIG. 4. - Styloptocuma darwini n. sp., immature 9 paratype (MNHN Cu1137): A, antenna 1; B, maxilliped 3; C, pereopod 1; D, pereopod 2; E, pereopod 3; F, pereopod 4; G, pereopod 5; H, uropod (before treatment with lactic acid). Scale bar: $0.2 \mathrm{~mm}$.

spines on the outer margin and another dorsally (these serrations disappeared after treatment with lactic acid); endopod 1-articulate with four simple setae on inner margin and one terminally; exopod 2-articulate, shorter than endopod, with a simple setae longer than the second article terminally. 


\section{REMARKS}

The new species described above belongs clearly to the genus Styloptocuma in having a narrow eyelobe without visual elements extending beyond the tip of pseudorostral lobes and a long peduncle of uropods. Petrescu (2000) added some characters to the diagnosis of this genus studying in detail some species from the Atlantic Ocean and pointed out the importance of some features of the antenna 1 and the mouth appendages. Styloptocuma darwini n. sp. has some of these features such as a tubercle on the second article of antennal peduncle, maxilla with a row of small setae between the margin of the protopod and the endites and carpus of maxilliped 1 with hand-like setae. However, it seems to have only a single terminal seta on the palp of maxillula instead of two reported by Petrescu (2000). This character was not mentioned in the descriptions of the Australian species written by this author (Petrescu 2006) and nor those from the Angola Basin by Mühlenhardt-Siegel (2005). The number of setae on the maxillula palp may be a variable character within the genus.

Styloptocuma darwini n. sp. resembles $S$. pleonserratum Mühlenhardt-Siegel, 2005 from the Angola Basin and S. spinosum Petrescu, 2006 from the southeastern Australian slope but differs from both by having a serrate antennal notch margin and transversal rows of spines on pereonites.

\section{ECOLOGICAL DATA}

The new species was found at vent sites of two SW Pacific back-arc basins (Fig. 1): the Lau Basin (Tu'i Malila, $1891 \mathrm{~m}$ detph, and Hine Hina, 1845 m depth), and the North Fiji Basin (White Lady, $1990 \mathrm{~m} \mathrm{depth}$ ). The habitat and associated fauna description of the two vent areas was given by Zelnio \& Hourdez (2009) for Tu'i Malila site, Desbruyères et al. (1994) for the Hine Hina and White Lady sites, and Komai \& Segonzac (2004) for the White Lady site.

The Tu'i Malila site, explored during dive 144, is composed of numerous active and inactive chimneys erected on a basaltic substrate, with depressions filled with hydrothermal sediments. Cumaceans were collected in or above these sediments by the slurp gun, at the same time as various other in- vertebrates: polychaeta and amphipods, galatheid crabs Munidopsis lauensis Baba \& de Saint Laurent, 1992, crabs Austinograea alayseae Guinot 1989, alvinocaridid shrimps, including Nautilocaris saintlaurentae Komai \& Segonzac, 2005 and Alvinocaris komaii Zelnio \& Hourdez, 2009. Video records were taken by the ROV Jason II submersible, they show other typical chemoautotrophic fauna on the wall or at the base of the active chimneys emitting transparent vent fluids at $5-15^{\circ} \mathrm{C}$, such as the mussel Bathymodiolus brevior von Cosel, Métivier \& Hashimoto, 1994, and the gastropods Alviniconcha hessleri Okutani \& Ohta, 1988, Ifremeria nautiliei Bouchet \& Warén, 1991, and Eosipho desbruyeresi Okutani \& Ohta, 1993.

The Hine Hina site, explored during dive 146, is formed by a massive sulphide deposit through which a widespread discharge of low-temperature $\left(<40^{\circ} \mathrm{C}\right)$ fluid occurs (Desbruyères et al. 1994). The slurp gun was used along the wall of an active chimney, among vent gastropds, and at the base, near sulphide rocks, among numerous small galatheid crabs Munidopsis lauensis, and barnacles Vulcanolepas sp. The fauna collected was composed of vent polychaete worms, siphonostoma copepods, amphipods and isopods, crabs $A$. alayseae, and alvinocaridid shrimps.

At the White Lady site (dive 152), the vent fauna occurs around some small chimneys emitting a translucent fluid at $285^{\circ} \mathrm{C}$ (Desbruyères et al. 1994). The video showed communities similar to the previously mentioned vent areas. The fauna collected during the dive was composed of various vent polychaeta worms, siphonostoma copepods, vent gastropods, as for Tu'i Malila, as well as barnacles Eochionelasmus ohtai Yamaguchi, 1990, crabs Austinograea alayseae, galatheid crabs Munidopsis starmer Baba \& de Saint Laurent, 1992, and shrimps Nautilocaris saintlaurentae, and Alvinocaris spp.

\section{ORIGIN OF HYDROTHERMAL VENT CUMACEAN FAUNA}

Although initially some authors postulated a paleozoic origin for the hydrothermal vent invertebrate fauna (Newman 1985), molecular and fossil record 
studies supported a relatively recent radiation or re-radiation of the modern vent taxa, suggesting that they invaded vents repeatedly during the Cenozoic (Little \& Vrijenhoek 2003). Fossil cumaceans go back to the Paleozoic (Malzahn 1972; Schram et al. 2003) when they had a pair of lobed and faceted eyes, a character lost in all extant species and apparently also in a Middle Jurasic specimen (Bachmayer 1960). In addition, phylogenetic analyses based on molecular data suggest Pseudocumatidae Sars, 1878 as the most basal family, while Leuconidae Sars, 1878, Bodotriidae Scott, 1901 and Nannastacidae were the most derived families (Haye et al. 2004). The currently known vent species belong to these last two families, suggesting that current cumacean vent taxa are not relict species.

Among the modern vent cumaceans, Bathycuma brevirostre and Atlantocuma bidentatum most likely colonized hydrothermal environment from the surrounding deep-sea habitat where they are widely distributed.

The above-described Styloptocuma darwini n. sp. belongs to a deep-sea phylogenetic lineage of the family Nannastacidae that is characterized, among other features, by a long eyelobe (Watling 1991). At the moment there is no indication that allow us to know if it inhabits deep bottoms of the west Pacific or are exclusive of the vent environment. At any rate, everything seems to indicate that it colonized vents from the deep sea.

Conversely, Thalycrocuma sarradini has been associated with other shallow-water nannastacid genera (Corbera et al. 2008) and could have colonized deep-sea vents from shallow-water vents or cold seeps, which acted as refugia during global anoxic events in the deep sea, as proposed by Jacobs \& Lindberg (1998). The mentioned relation with shallow-water allies and features such as the high number of sensory setae on the antennula not found in other Nannastacidae, suggest the endemicity to the hydrothermal environment for this genus.

Although hydrothermal vent cumacean fauna is still poorly known, the first steps on their origin proposed above tend to indicate that its history has not been very different from that proposed for other zoological groups.

\section{Acknowledgements}

We thank R. C. Vrijenhoek (Monterey Bay Aquarium Research Institute, USA), Chief Scientist of the cruise TUIM06MV, and the crew of RV Melville and ROV Jason II for the collection of the samples. We thank also S. Johnson (Monterey Bay Aquarium Research Institute, USA) for making available the video tape of the dives, S. Hourdez (Centre national de la Recherche scientifique, Roscoff, France) for his valuable comments on ecological data, and Sarah Gerken (University of Alaska, Anchorage) and Iorgu Petrescu (National Museum of Natural History Grigore Antipa, Bucharest) for their useful suggestions improving the manuscript.

TheTUIM06MV expedition was funded by grant from the US National Science Foundation to R. C. Vrijenhoek (OCE-0241613) and C. L. Van Dover (OCE-0350554).

\section{REFERENCES}

BăCesCu M. \& Muradian Z. 1974. - Campylaspenis, Styloptocuma, Atlantocuma, new genera of Cumacea from the deep waters of the Atlantic. Revue roumaine de Biologie 19 (2): 71-78.

BĂCESCU M. \& PetresCU I. 1999. — Ordre des Cumacés (Cumacea Krøyer 1846), in FOREST J. (ed.), Traité de Zoologie, Tome VII, Fascicule IIIA, Crustacés Péracarides. Mémoires de l'Institut océanographique, Monaco 19: 391-428.

BaChmaYer F. 1960. - Eine fossile Cumaceenart (Crustacea, Malacostraca) aus dem Callovien von La Voulte-sur-Rhône (Ardèche). Eclogae Geologicae Helvetiae 53: 422-426.

Corbera J. 2006. - Arthropoda, Crustacea, Cumacea, in Desbruyères D., Segonzac M. \& Bright M. (eds), Handbook of deep-sea hydrothermal vent fauna. Denisia 18: 370-371.

Corbera J., Segonzac M. \& Cunha M. R. 2008. A new deep-sea genus of Nannastacidae (Crustacea, Cumacea) from the Lucky Strike hydrothermal vent field (Azores Triple Junction, Mid-Atlantic Ridge). Marine Biology Research 4: 180-192.

Corbera J., San Vicente C. \& Sorbe J.-C. 2009. Cumaceans (Crustacea) from the Bellingshausen Sea and off the western Antarctic Peninsula: a deep-water link with fauna of the surrounding oceans. Polar Biology 32: 611-622.

Desbruyères D., Alayse-Danet A.-M., Ohta S. \& THE SCIENTIFIC PARTIES OF BIOLAU AND STARMER CRUISES. 1994. - Deep-sea hydrothermal com- 
munities in Southwestern Pacific back-arc basins (the North Fiji and Lau basins): composition, microdistribution and food web. Marine Geology 116: 227-242.

Desbruyères D., Segonzac M. \& Bright M. (eds) 2006. - Handbook of Deep-Sea Hydrothermal Vent Fauna. Denisia 18: 1-544.

Haye P., Kornfield I. \& WatLing L. 2004. — Molecular insights into Cumacean family relationships (Crustacea, Cumacea). Molecular Phylogenetics and Evolution 30 (3): 798-809.

JACOBS D. \& LindBERG D. 1998. - Oxygen and evolutionary patterns in the sea: onshore offshore trends and recent recruitment of deep-sea faunas. Proceedings of the National Academy of Sciences USA, 95: 9396-9401.

Jones N. S. 1984. - The family Nannastacidae (Crustacea: Cumacea) from the deep Atlantic. Bulletin of the British Museum (Natural History), Zoology Series 46: 207-289.

Jones N. S. \& SANDers H. L. 1972. - Distribution of Cumacea in the deep Atlantic. Deep-Sea Research 19: 737-745.

Komai T. \& Segonzac M. 2004. - A new genus and species of alvinocaridid shrimp (Crustacea: Decapoda: Caridea) from hydrothermal vents on the North Fiji and Lau basins, South-Western Pacific. Journal of the Marine Biological Association of the U.K. 84: 1179-1188.

LitTLE C. \& VRIJENHOEK R. 2003. - Are hydrothermal vent animals living fossils? Trends in Ecology and Evolution 18 (11): 582-588.

MalzAHN E. 1972. - Cumaceenfunde (Crustacea,
Malacostraca) aus dem niederrheinischen Zechstein. Geologisches Jahrbuch 90: 441-462.

MÜHLENHARDT-Siegel U. 2005. - Cumacea species (Crustacea: Peracarida) from the deep-sea expedition DIVA-1 with RV "Meteor" to the Angola Basin in July 2000. Family Nannastacidae. Organisms Diversity and Evolution 5: 151-170.

NEWMAN W. A. 1985. - The abyssal hydrothermal vent invertebrate fauna: a glimpse of antiquity? Bulletin of the Biological Society of Washington 6: 231-242.

PetresCu I. 2000. — Remarks on the genera Schizocuma Băcescu, 1972 and Styloptocuma Băcescu \& Muradian, 1974 (Crustacea, Cumacea). Bulletin of the Natural History Museum of London (Zoology) 66 (2): 147-166.

Petrescu I. 2006. - Nannastacidae (Crustacea: Cumacea) from the eastern Bass Strait, the south-eastern Australian slope, and Antarctica in the collections of Museum Victoria. Memoirs of Museum Victoria 63: 129-173.

Schram F., Hof C., Mapes R. \& SNOWdOn P. 2003. Paleozoic cumaceans (Crustacea, Malacostraca, Peracarida) from North America. Contributions to Zoology 72 (1): 1-16.

WATLING L. 1991. - Rediagnosis and revision of some Nannastacidae (Crustacea: Cumacea). Proceedings of the Biological Society of Washington 104 (4): 751-757.

Zelnio K. A. \& Hourdez S. 2009. - A new species of Alvinocaris (Crustacea: Decapoda: Caridea: Alvinocarididae) from hydrothermal vents at the Lau Basin, southwest Pacific, and a key to the species of Alvinocarididae. Proceedings of the Biological Society of Washington 122 (1): 52-71. 